\title{
Levonorgestrel-Releasing Intrauterine System
}

National Cancer Institute

\section{Source}

National Cancer Institute. Levonorgestrel-Releasing Intrauterine System. NCI Thesaurus. Code C52193.

\begin{abstract}
A long-acting, hormone-releasing, intrauterine device consisting of a small, T-shaped, polyethylene frame and a reservoired synthetic progesterone with progestational and potential antineoplastic activities. After insertion of this system into the uterus, the device slowly and gradually releases the hormone. Levonorgestrel acts by binding to the progesterone receptor in the nuclei of target cells, resulting in transcription activation and an alteration in protein synthesis. Subsequently, luteinizing hormone (LH) activity and ovulation are suppressed. Levonorgestrel may also exhibit antiproliferative activity in endometrial tissue.
\end{abstract}

